\title{
LEGAL PROTECTION OF WORKERS IN THE WORK AGREEMENT ON OUTSOURCING SYSTEM IN INDONESIA
}

\author{
Fithriatus Shalihah \\ Faculty of Law, Universitas Islam Riau \\ Email: fithriatus@law.uir.ac.id
}

\begin{abstract}
In the outsourcing system, it is certain that the working relationship between employer and worker is a working relationship with a particular Time Agreement. This status becomes a problem because there is no certainty about the continuity of the employment relationships and the non-fulfillment of the rights that workers should receive, thus this is harming the workers economically and socially. The regulation related to the outsourcing system that stated in the Law Number 13 of 2003 on Labor Law is also difficult to implement in a business world since the existing rules do not meet the needs of the labor market. Company does not make the flow of production activities so that it is unclear and no legal certainty about the nature and types of core business and non core business activities. In the implementation of job protection and work requirements for outsourced workers, the government should enhance its role in the supervision and enforcement of labor law through the quantity and quality of labor inspectors.
\end{abstract}

\section{Keywords: Outsourcing, Employment Relationship.}

\section{A. INTRODUCTION}

Development is an effort to create prosperity and prosperity for people. Therefore, the results of development should be enjoyed by all people as an improvement of the welfare, both material and spiritual in a fair and equitable way (FX Djumiadji, 1987: 1).

Employment development is an integral part of national development based on Pancasila and the 1945 Constitution, implemented in the framework of the complete development of the Indonesian people and the development of the whole Indonesian society to improve the dignity and dignity of workers and to create a prosperous, just, prosperous and equitable society, both material and spiritual (General Elucidation, 2003: 13). 
Legal protection of workers is the fulfillment of the basic right inherent and protected by the constitution as stipulated in Article 27 paragraph (2) of the 1945 Constitution, states that:

"Every citizen shall have the right to work and to earn a humane livelihood".

The Article above affirms essentially that work and earn reasonable remuneration and fair treatment in employment relations is the basic right of every citizen, so that the state is obliged to seek the availability of employment for its citizens and to set up a just employment system so that the workers and their families can live a decent life.

The protection of workers is intended to secure the basic rights of workers and guarantee equality and treatment without discrimination on any grounds to realize the welfare of workers and their families by keep paying attention on the progress of the business world.

Social protection for workers aims to make workers are respected for their dignity as human beings, not just as a factor of production, while the economic protection of workers aims to enable workers to enjoy decent income in order to meet the needs of life for themselves and for their families (Aloysius Uwiyono, 2003: 10).

Differences in views and principles between the interests of law (protection of workers) and the interests of the economy (business world / company profit), causes a gap between the necessity (das sollen) and reality (das sain). The law requires the fulfillment of the rights of the workers maximally while the company perceives it as an obstacle / burden because it will reduce the company's profits. The importance of protection for workers is usually faced with the interests of the entrepreneur/employer to survive in running his business (Eggy Sudjana, 2005: 1).

Government has been mandated in the constitution to provide protection, enforcement and fulfillment of human rights. In terms of employment, the government is expected to provide guarantees on workers' rights. 
The indications of weak legal protection for workers can be seen from the problem of outsourcing which is still an actual national issue. The problem of outsourcing is varies as outsourcing is increasingly used widely in the business world in Indonesia, while the existing laws inadequate to regulate outsourcing that has been running in the midst of the life of the business world.

According to Yasar Iftida, if we watch the news in the media, outsourcing seems to be a terrible thing. Outsourcing is considered a new style of slavery. It does not protect workers, there is a practice of wage cuts and the workers have no protection and legal certainty. Their status is always as temporary workers. This condition triggers the emergence of demands from workers to eliminate/remove outsourcing system (Iftida Yasar, 2011: 1).

Outsourcing problem in Indonesia is increasing as the implementation of outsourcing is legalized by Law Number 13 of 2003 on Labor Law which brings up controversy which is motivated by the concept of thinking of each different parties.

For those who agree on outsourcing argues that outsourcing is useful in the development of business world, spur the growth of new business (vendor) which indirectly opens employment for job seekers, while those who disagree on the legalization of outsourcing is motivated by the idea that this system will harm workers and will provide the widest opportunity for employers to dominate industrial relations.

If reviewed from a sociological law enforcement that contains the effectiveness of the law based on the acceptance or recognition of those being targeted, the legalization of outsourcing is indeed problematic since in reality the outsourcing system is opposed by most of the people (workers) who have been wanting the quality improvement to meet the basic rights of workers.

The reform era that was at first expected to be able to build and create more open and democratic legal, social, political, economic and cultural conditions, in fact has not been felt by workers. The obstacles of all these expectations start from the imbalance of the labor law system, i.e structural 
obstacles, substantive and cultural legislation or policies, as well as financial barriers that cause a weak supervision and enforcement of labor laws from the government, lack of job protection or employment conditions from employers to the workers/employee.

The weak of legal protection of workers, especially contract workers (PKWT) who work in companies with outsourcing system can be seen from the number of violations of work protection and working conditions along with the norms of Occupational Health and Safety done by the employer/entrepreneur in running outsourcing business. The violations are as follows:

1. The Company does not clarify the core business and non-core business which is the basis of outsourcing, so in practice the outsourced work is the core work of the company. The lack of clarification of the nature and type of outsourced work resulted in workers being employed for basic types of work or work directly related to the production process, not the supporting activities as required by law.

2. A company that submits a work leaves some of its work to other companies / vendors that are not legal entities.

3. Working protection and requirements for outsourced workers are very minimal compared to other workers working directly for principal companies and/or not in accordance with applicable laws and regulations. The facts and incidents that often occur are:

a. A working relationship between workers and the vendor is not made in written form of the employment agreement, so that the status of the worker becomes unclear whether it is based on the Work Agreement for a Specified Time Period (PKWT) or Work Agreement for an unspecified Time Period (PKWTT), due to this uncertainty status, the worker can be terminated from his working relationship without any conditions. 
b. Vendors pay low wages which is not according to a minimum wage standards and the need for decent living for workers.

c.

Working hour or resting periods for workers is not implemented well, and the calculations of overtime wages not in accordance with the Decree of the Minister of Labor Law and Transmigration Number 102 / Men / VI / 2004 on Overtime and Overtime Wages.

d. Outsourced workers are excluded from the Social Insurance (JAMSOSTEK) program which includes Work Accident Insurance (JKK), Death Insurance (JKM), Old Age Security (JHT) and Health Insurance (JPK). Employers also do not provide health-enhancing services for workers and their families.

e. In general, vendors do not apply Occupational Safety and Health (K3) norms for workers.

f. As a contract worker, outsourced workers have no guarantees in job security and career development. They are not given severance payment after termination and other basic rights are not met before, during and after work.

The complexity of the outsourcing problem in terms of hand over some parts of work to other companies through employment contracting agreements as well as agreement on providing workers services require equal attention from the government between the need of investors to development business world and the legal protection of workers since in practice there are many violations of the provisions and terms of implementation of outsourcing.

In this context the government should immediately seek a solution because nowadays there is a perception that companies including companies engaged in outsourcing (vendor) are established for the interests of employers/entrepreneurs and capital owners only. In fact, the public also has an interest in the company's performance in terms of providing products and services, creating employment opportunities and absorbing job seekers. The 
government itself is concerned that the community can be prosperous so there is a sense of peace and security (Adrian Sutedi, 2009: 38).

Based on the above description, the writer is interested to know and conduct further study on legal protection against outsourced workers (outsourcing). It encourages the writer to conduct legal writing entitled: "Legal Protection of Workers in The Work Agreement on Outsourcing System in Indonesia"

\section{B. PROBLEM STATEMENT}

Based on the background of this study so the problems of this research are:

1. How is outsourcing matter according to Law Number 13 of 2003 on Labor Law?

2. How does the implementation of work protection and work requirements for outsourced workers?

\section{RESEARCH METHODS}

1. Types and Nature of Research

When viewed from the type of research then this research is normative legal research. This research was conducted by reviewing library materials or secondary data only. The author obtains and collects data based on the study of literature in the form of books and other literatures, bibliography/references along with complementary data that the author obtained from mass media such as newspapers, magazines, internet and others.

If viewed from the nature of research, this research is classified as descriptive research because the author intends to describe the systematic, bright and detailed about the main issue that is studied deductively.

2. Source of Data

The data used by the author in compiling this legal writing is from secondary data. Secondary data is a data obtained from the library 
materials. The secondary data from this research is differentiated as follows"

1. Primary Material

Primary Law Data is legal material that consists of: a) Civil Code; b) Law Number 13 of 2003 on Labor Law; c) Law Number 3 of 1992 on Social Security of Labor; d) Ministry of Labor Law Regulation Number Per-01 / Men / 1998 on the Implementation of Health Maintenance for Workers; e) Decree of the Minister of Labor Law Number 150 / Men / 1999 on the Implementation of Social Security Program for Freelance Labors, Labor Supply and Working Agreements for a Definite Time Period. F) Decree of the Minister of Labor Law and Transmigration Number 19 Year 2012 of Labor Supply Agreement.

2. Secondary Material

Secondary Law Material is the legal material that provides explanation of the primary legal materials i.g, magazines, newspapers, internet, etc related to Labor Law.

3. Data Analysis

Analysis is to group and make a sequence and eliminate data so it will be easy to read. Analysis of data that the author used in this legal research is from the data that the author has earned and collected from primary and secondary law materials in the form of library books, then from the data author summarized them by making grouping based on the types of books in a structured and systematic way to be processed then presented into the form of systematic sentences, by comparing the theories, experts opinions, laws and regulations on labor law especially on issues related to Outsourcing.

The author then draw the conclusions of what she obtained by referring to the purpose of research. The conclusion of this research is determined by deductive method which is by taking the result of conclusion from the general to the specific things. In this case, in 
general are the rights and obligations between employers and workers, which are applied in the outsourcing agreement to be drawn specifically.

\section{RESEARCH RESULT AND DISCUSSION}

\section{Outsourcing Viewed From Law Number 13 of 2003 on Labor Law Terms for Making Outsourcing Work Agreement}

The regulation concerning the establishment of an outsourcing cooperation/work agreement is provided in Article 64 of Law Number 13 of 2003 on Labor Law, which states explicitly that the contract of employment or the provision of services of workers, shall be made in writing.

In its development the term contract has been given a more specific meaning of a written agreement, thus the term contract always contains the meaning of "agreement" and "writing" (Djoko Trlyanto, 2004: 56).

The outsourcing agreement is the agreement between the employer and the vendor regarding the outsourcing business, resulting in rights and obligations in outsourcing practices between the two parties, including their obligations to fulfill the rights of outsourced workers.

The outsourcing cooperation agreement must satisfy the following four conditions as stated in the Article 1320 of the Civil Code in order to be valid:

1. There must be consent of the individuals who are bound thereby;

2. There must be capacity to conclude an agreement;

3. There must be a specific subject;

4. There must be an admissible cause, which is permissible and / or not contrary to the rules of law, public order and morality. The first and the second condition are referred to as subjective conditions, because it concerns "the person" or the parties, while the third 
condition the fourth condition are called objective requirements because they concern the object of the agreement.

The non-fulfillment of the subjective terms resulted in the cancellation of an agreement by either party. This means that even if the Agreement has been signed, one of the parties who objected to the process of the treaty can submit a cancellation of the contents of the agreement to the court. Whereas if the objective conditions are not fulfilled then the agreement is null and void, that means the contents of the agreement do not bring any effect to both parties because legally the agreement was considered never existed.

The outsourcing contract applies the subjective requirements and objective terms. Therefore, the principal and vendor must pay attention and fulfill the outsourcing requirements as stated in the provisions of Article 64, Article 65 and Article 66 of Law Number 13 of 2003 on Labor Law and Decree of Minister of Labor Law and Transmigration Number 220 / Men / X / 2004 on conditions for the hand-over of part of work executions to other companies, stating that:

1. The handover of part of work from an enterprise to another enterprise [a contractor] shall be performed under a written agreement of contract of work.

2. Work that may be handed over to the other enterprise as referred to under subsection (1) must meet the following requirements:

a.The work can be kept separate from the main (business) activity (of the enterprise that contracts the work to the other enterprise);

b. The work is to be undertaken under either a direct order or an indirect order from the (original) party commissioning the work;

c. The work is an entirely auxiliary activity of the enterprise (that contracts the work to the other enterprise); and

d. The work (when pending completion while being contracted out to the other enterprise) does not directly inhibit the production 
process (of the enterprise that subcontracts the work to the other enterprise).

3. The other enterprise as referred to under subsection (1) must be a legal entity.

4. The protection and working conditions provided to workers/ labourers at the other enterprise as referred to under subsection (2) shall at least the same as the protection and working conditions provided at the enterprise that commissions the contract or shall accord with valid laws and regulations.

5. Any change and/or addition to what is required under subsection (2) shall be determined and specified further with a Ministerial Decision.

The above provision is an objective requirement, because it is a provision that is expressly and clearly regulated in the laws and regulations of labor. Violation of the above conditions, in some or whole part may result in null and void of the outsourcing cooperation agreement. It means that the contents of the agreement do not bring any legal consequences to both parties because legally the agreement was considered never existed. Based on Article 65 paragraph (8) and Article 66 paragraph (4) if the provisions which are the objective terms of the outsourcing cooperation agreement are not fulfilled then all things related to employment, especially the status of employment relationship between the worker/ labourer and the labour provider shall change into employment relationship between the worker/ labourer and the enterprise that commissions the labour provider

To provide legal certainty regarding the rights and obligations of the principal and the vendor, Outsourcing contract / agreement must contain the whole agreement points on cooperation that become the object of cooperation or agreement to meet the provisions and conditions of outsourcing including the willingness of the parties to fulfill the right of workers' basic rights in accordance with labor laws and regulations. 
In practice, the outsourced cooperation / contract agreement only contains an agreement to carry out a particular job with a certain general payments without making detailed clauses about the classification of the nature and the type of work. It also does not make the process flow of activities, working protection and conditions for workers.

Outsourcing contract / contractual agreements that are unclear and detailed about the nature and type of work subcontracted to be outsourced causes the principal to freely and arbitrarily hire outsourced workers for the main activities of the company. Similarly, outsourced cooperation / contract agreements that do not contain clauses about working protection and conditions will result in a non-fulfillment of employment protection and work conditions which are the basic rights of workers.

\section{Terms and Conditions of Legal Entity of Outsourcing Company (Vendor)}

The subject of law is a person with rights and obligations that have the authority and ability to do and not to do something. Regarding the authority and ability of the recipient company (vendor) to run the outsourcing business is regulated and limited by the Article 65 paragraph (3) and Article 66 paragraph (3) of Law Number 13 of 2003 on Labor Law. Article 65 paragraph (3), states that:

"The other enterprise as referred to under subsection (1) must be a legal entity."

Article 66 paragraph (3) states that:

"Labour providers/ suppliers shall take the form of a legal entity business with license from a government agency responsible for labour/ Labor Law affairs"

Basically, both of the above provisions stipulate that a company that can carry out the job or the provision of services of workers is a company with a legal status. The background of stipulating this requirement is to outsourcing companies are not too easy to release 
responsibility and liability toward workers and other third parties (Sehat Damanik, 2006: 87).

For a service provider company, its operational legality must be a legal entity and must also have an operational license from the responsible agency in the Labor Law field in the regency / municipality in accordance with the domicile of the worker's service provider company. Based on the provisions of Decree of Minister of Labor Law and Transmigration Number 101 / Men / V / 2004 on Licensing Procedure for Service Provider Company, it is determined that to obtain operational license of worker service, the company has to submit application by sending documents as follows:

a. Copy of endorsement of a company as a legal entity of Limited Liability Company or cooperative;

b. Copy of the articles of association in which includes the business activities of workers' services;

c. Copy of Business License (SIUP);

d. Copy of Mandatory Report on Employment.

The Municipal / Regency Labor Law Office must have issued an operating license to the application which has fulfilled the above requirements within 30 (thirty) days of of the application.

Companies / business entities that have status as legal entity are Limited Liability Company (PT), foundation and cooperative. While individual companies, firms and commanditaire vennootscha (CV) are not institutionally incorporated as legal corporations, they do not have the legal authority and ability to act as legal subjects in the outsourcing business.

Because CV and Firms are individual companies, they do not have authority, ability, and right to engage in outsourcing relationships so an outsourcing contract cooperation agreement involving a non-legal entity is null and void for violating the objective terms of an agreement. Since such agreements are made null and void, any legal consequences 
arising from the agreement including the fulfillment of the rights of the outsourced worker becomes the responsibility of the company which gives the work (principal), this is stated in Article 4 paragraph (8) and Article 66 paragraph (4).

The application of legal entities in the practice of outsourcing requires full responsibility of the employer (vendor) in the form of a guarantee the fulfillment of the basic rights of workers which has been set by law must at least the same as the protection and working conditions provided at the company that commissions the contract or in accordance with applicable laws and regulations.

Violation of these legal entities constitutes a violation of objective terms in terms of the outsourcing contract, so that the juridical agreement between the principal and the non-legal vendor is null and void. Consequently, the principal is responsible for the fulfillment of the rights of the outsourced worker. The employee/worker shall be legally bound in the working relationship with the principal since the nonfulfillment of such conditions.

One of the factors that caused the number of vendors who are not legal entity due to the contradiction between the Decree of Minister of Labor and Transmigration Number 220 / Men / X / 2004 on conditions for the hand-over of part of work executions to other companies. and Article 65 paragraph (5) -Act Number 13 Year 2003 on Labor .

Based on Article 65 Paragraph (5) of Law Number 13 of 2003 on Labor, the Minister of Labor and Transmigration may only change and / or add the Terms as intended in paragraph (2) but in fact, in addition to supplementing the Terms as set forth in paragraph (2) of Law Number 13 of 2003 on Labor, the Minister also provides an exception to the provisions of Article 65 paragraph (3), which are exceptions to legal entities for companies that accept employment (vendor).

The contradiction of outsourcing arrangements opens opportunities for employers to override the terms and conditions of 
outsourcing, especially regarding the legal requirements for vendors. In addition, it is also against the principles of legislation.

In the rule of law norms there is no justification for the contradiction between lower legal norms and higher legal norms (Esmi Warasih, 2005: 33). Therefore, the Decree of the Minister of Labor and Transmigration Number 220 / Men / X / 2004 on the Condition for the Hand-Over of Part of the Work Executions to Other Companies shall be ruled out. Therefore, in relation to legal certainty (regarding legal requirements in the practice of outsourcing) the requirements that must be used by the vendor are the provisions of Article 65 paragraph (3) and Article 66 paragraph (3) of Law Number 13 of 2003 on Labor .

\section{The requirements of Outsourced Jobs}

Basically, the main objective of an outsourcing company is to set company's competency strategy to focus on its core business. Competition between companies generally involves three things, namely: product price, product quality and service.

However, not all jobs can be handed over to other companies by outsourcing, only those that meet certain terms that can be handed over to the other company.

In this case the company may hand over some part of work executions to other companies through:

a. Outsourcing contractor

b. Labor Supplier

Based on the provisions of Article 65 paragraph (2), the work which may be handed-over to other companies shall meet the following conditions:

a. The work can be kept separate from the main (business) activity.

This means that the work is not done simultaneously with the main principal activities. This provision is intended to improve the main business focus and avoid any abuse of the use of outsourced workers by the principal. 
b. The work is to be undertaken under either a direct order or an indirect order from the (original) party commissioning the work.

This means that outsourcing activities can be done in the vendors' or principal' place in accordance with the nature of work in outsource. For the work that is in a particular product, the work can be done in the vendor's company environment and work order can be given by the principal through the vendor. Whereas for the work - a job that that performs a particular service is usually done in the environment of the principal company, and orders can be given directly by the principal.

c. The work is an entirely auxiliary activity of the enterprise.

Based on the provisions of Article 66 paragraph (1) along with the explanation, then what is meant by auxillary activity/activity that is not directly related to the production process is the activity outside the core business of a company.

d. The work does not directly inhibit the production process

This means that the hand-over work does not directly affect the production process so that if there is obstacle experienced by vendor in fulfilling its performance, it will not inhibit the production process directly and / or not shut off the activity of principal company. The provisions concerning the limitation of outsourcing executions as stipulated in Article 65 paragraph (2) is a cumulative requirement, which means it must be fulfilled jointly at the time of execution. If any and / or all of the terms are not met, the outsourced work can not be handed over and the outsourcing contract / agreement / contract is null and void.

The terms of employment which may be handed over to other companies shall also be governed by Article 6 paragraph (1) of the Decree of Minister of Labor and Transmigration Number 220 / Men / X 
/ 2004 on Condition for hand-over of Part of the work to Other Companies, which states the following :

The work that may be handed over to the contractor should meet the following requirements:

1. The work is carred out separately from the main (business) activity.

2. The work is to be undertaken under either a direct order or an indirect order from the employer. It is intended to give an explanation of how to carry out the work to conform the standards set by the employer

3. The work is an entirely auxiliary activity of the enterprise. It means the activity is an activity that supports and facilitates the implementation of work in accordance with the workflow of the employer.

4. The work does not directly inhibit the production process means that the activity is an additional activity that if not done by the employer company, the main job execution process is still running as usual.

Just as a violation of the terms of a legal entity, a violation of the Terms of Work can be null and void an outsourcing contract as it opposed the Article 65 paragraph (2) of Law Number 13 of 2003 on Labor and Decree of Minister of Labor and Transmigration Number 220 / Men / X / 2004 on Condition for the Hand-Over of Part of Work to Other Companies.

\section{Implementation of Work Protection and Working Conditions For Outsourcing Workers}

1. Work Protection

Implementation of the obligations of employers to outsourced workers is stipulated in Article 65 paragraph (4) of Law Number 13 of 2003 on Labor, which states: 
"The protection and working conditions provided to workers/ labourers at the other enterprise as referred to under subsection (2) shall at least the same as the protection and working conditions provided at the enterprise that commissions the contract or shall accord with valid laws and regulations"

According to Djoko Triyanto, work protection covers a wide range of aspects which is the protection of physical that includes safety protection from work accident and health along with keeping work morale and treatment in accordance with human dignity, moral, and religion (Djoko Triyanto, 2004: 102).

Employment protection for workers in working relationships is generally stated in Law Number 13 of 2003 on Labor, such as:

a) Right to have equal opportunity and equal treatment without discrimination (Article 5, Article 6);

b) Right to improve and develop job competence through job training (Article 11, Article 12);

c) Equal rights and opportunities to choose, obtain, or move to another jobs (Article 31);

d) Right to have certainty in the employment relationship (article 50 to Article 66);

e) The right to work, rest, leave, overtime and overtime wages (Article 77 to Article 85);

f) Right to receive protection of health and safety, morals and morals treatment in accordance with human dignity and rights as well as the right to obtain death insurance from accident (Article 86, Article 87)

g) Rights relating to wages, social security and welfare (Article 88 to Article 101);

h) Right to form and become member of a trade/ labour union.

i) Right to strike (article 137 to Article 145);

j) Right to get severance pay after dismissal (article 156). 
Such rights are the basic rights of workers which are not all outsourced workers obtain. This is because the nature of the outsourced work itself, which is only the non-core business, and also in practice outsourcing entrepreneurs focus more on the principle of business by ignoring the basic rights of workers. Such conditions lead to low levels of worker motivation.

The emergence of negative impression on the legalization of outsourcing, leads to the treatment of entrepreneurs (vendors) who do not follow the provisions in implementing work protection and work conditions which are the basic rights of workers. A balance between the company's objectives and the fulfillment of the basic rights of the worker can be accomplished if the employer provides work protection and working conditions for the employee by applying the work norms and occupational safety and health norms in the company. The protection is intended for workers to safely perform their daily work so as to increase production and work productivity.

2. Terms of Working Conditions

a) Implementation of Terms of Employment

Employment relationship is the relationship between workers and employers that occur after the employment agreement. In Article 1 number 15 of Law Number 13 of 2003 on Labor stated that:

"An employment relation or relationship shall be defined as a relationship between an entrepreneur and a worker/ labourer based on a work/ employment agreement, which deals with aspects relating to the job [that the worker has to do], the worker's wage, and orders and instructions (that the worker has to carry out)"

Working relationships occur because of employment agreements between employers and workers (Lalu Husni, 2007: 53). From this understanding it is clear that the employment relationship as a form of legal relationship is born or created after an employment agreement between workers and employers. 
In order that the employment relationship is not detrimental to either party especially the outsourced worker, Article 65 paragraph (6) and paragraph (7) of Law Number 13 of 2003 concerning Employment regulating the working relationship for the outsourcing system shall be in a written employment agreement between the workers and the employer (vendor), based on an Unspecific Time Working Agreement (PKWTT) or a Specific Time Working Agreement (PKWT) that must meet the requirements of Article 59 of Law Number 13 of 2003 on Labor, namely:

1.A work agreement for a specified period of time can only be made for a certain job, which, because of the type and nature of the job, will finish in a specified period of time, that is:

a. Work to be performed and completed at one go or work which is temporary by nature;

b. Work whose completion is estimated at a period of time which is not too long and no longer than 3 (three) years;

c. Seasonal work; or

d. Work that is related to a new product, a new type of activity or an additional product that is still in the experimental stage or try-out phase.

2.A work agreement for a specified period of time cannot be made for jobs that are permanent by nature.

3.A work agreement for a specified period of time can be extended or renewed.

4. A work agreement for a specified period of time may be made for a period of no longer than 2 (two) years and may only be extended one time for another period that is not longer than 1 (one) year.

5.Entrepreneurs who intend to extend work agreements for a specified period of time they have with their workers/ labourers shall notify the said workers/ labourers of the intention in writing 
within a period of no later than 7 (seven) days prior to the expiration of the work agreements.

6.The renewal of a work agreement for a specified period of time may only be made after a period of 30(thirty) days is over since the work agreement for a specified period of employment comes to an end; the renewal of a work agreement for a specified period of time may only be made 1 (one) time [once] and for a period of no longer than 2 (two) years.

7.Any work agreement for a specified period of time that does not fulfill the requirements referred tounder subsection (1), subsection (2), subsection (4), subsection (5) and subsection (6) shall, by law, become a work agreement for an unspecified period of time.

8. Other matters that have not been regulated under this article shall be further determined and specified with a Ministerial Decision.

The requirements for making Work Agreement for a Secified Time Period (PKWT) are divided into 2 (two) kinds, namely:

a. Material Requirements

Regulated in Article 52 paragraph (1) of Law Number 13 of 2003 on Labor :

a. The agreement of both sides;

b. The capability or competence to take legally-sanctioned actions;

c. The availability/ existence of the job which both sides have agreed about;

d. The notion that the job which both sides have agreed about does not run against public order, morality and what is prescribed in the valid legislation.

b. Formal Requirements

Regulated in Article 54 paragraph (1) of Law Number 13 of 2003 on Labor, which specifies that written work agreements shall contain at least the following: 
i. The name, address and line of business [of the enterprise];

ii. The name, sex, age and address of the worker/ labourer;

iii. The occupation or the type of job;

iv. The place, where the job is to be carried out;

v. The amount of wages and how the wages shall be paid;

vi. Job requirements stating the rights and obligations of both the entrepreneur and the worker/labourer;

g. The date the work agreement starts to take effect and the period during which it is effective;

h. The place and the date where the work agreement is made; and

i. The signatures of the parties involved in the work agreement.

If the material requirements are not met then the consequences of Specifc Time Work Agreement (PKWT) are null and void, and automatically it turns into Unspecific Time Working Agreement (PKWTT). Thus, employers should treat workers as permanent workers.

According to Libertus Jehani, the law prohibits to hire contract workers by verbal agreement. To hire contract workers, the employment agreement must be made in writing. If the employment agreement is made orally, then the consequence of the Specifc Time Work Agreement (PKWT) is changed to Unspecific Time Working Agreement (PKWTT) and thus the contract worker becomes permanent worker with all his rights attached to him (Libertus Jehanl, 2008: 6).

Furthermore, Libertus Jehani said the regulation regarding the terms of hiring contract workers is very limited. However, in practice there are irregularities. Jobs that are permanent in nature also use contract workers. Ironically because of the demands of the era of globalization, there are companies that change the system of work from the status of permanent workers into the contract system of work (Asri Wijayanti, 2009: 49). 
Labor supplier (vendor) company prefer to establish employment relationships with workers with specified time status (PKWT)/ employment contracts rather than unspecified time status (PKWTT) / permanent workers, as vendors see that employment relationships based on work contract systems are more efficient than those employing permanent workers as they view The Work Agreement for a Specified Time (PKWT) is not burdened with some things to employment issues such as wage, welfare, periodic wage increases, workers' social benefits, rest days or leave, and most importantly they are not burdened by issues related to severance pay or gratuity award at the time of termination of employment relationship.

b) Wages Requirements

Wages are the remuneration that workers receive on the services they provide in the process of producing other goods or services in the enterprise, thus the workers and employers have a direct interest in the wage system and conditions in each enterprise. One of the obligations of employers as a result of the employment relationship is to pay wages. In general wages are payments that workers receive during their work (Zainal Aslkin dan Agusfian Wahab, 1993: 86).

Based on Article 2 of Law Number 8 Year 1981 on Protection of Wages, it is stated that:

"The right to receive wages arises at the time of the employment relationship and ends at the time the employment relationship is terminated".

The legal basis of remuneration is Article 27 paragraph (2) of the 1945 Constitution which states:

"Every citizen shall have the right to work and to earn a humane livelihood." 
The Article above is further elaborated in Article 88 of Law Number 13 of 2003, which states:

1) Every worker/ labourer has the right to earn a living that is decent from the viewpoint of humanity [literal: the right to earn an income that meets livelihood that is decent for humans].

2) In order to enable the worker to earn a living that is decent from the viewpoint of humanity as referred to under subsection (1), the Government shall establish a wage policy that protects the worker/ labourer.

3) The wage policy that protects workers/ labourers as referred to under subsection (2) shall include:

a. Minimum wages;

b. Overtime pay;

c. Wages that are payable to the worker during his absence from work due to illness;

d. Wages that are payable to the worker during his absence from work because of activities outside of his job that he has to carry out;

e. Wages payable to the worker during his absence from work because he uses his right to take a rest;

f. The form and method of the payment of wages;

g. Fines and deductions from wages;

h. Things that can be calculated with wages;

i. Proportional wage structure and scale;

j. Wages for the payment of severance pay; and

k. Wages for calculating income tax.

4) The Government shall establish/ set minimum wages as referred to under subsection (3) point (a) based on the need for decent living by taking into account productivity and economic growth.

Income that meets a decent livelihood is the amount of income earned from the work so that it can meet the needs of the 
workers and their families in a reasonable way that includes food and beverages, clothing, housing, education, health, recreation, and old age.

The standard wage for workers is the minimum wage, which is the lowest monthly wage consisting of basic wages including fixed allowances. Article 90 paragraph (1) of Law Number 13 of 2003 stipulates that employers are prohibited from paying wages lower than minimum wages, ie wages based on minimum living needs, consumer price index, ability, development and sustainability of enterprises, wages generally apply in certain areas, labor market conditions, as well as the level of economic development and per capita income.

Employment inspectors should oversee the application of wages in outsourcing practices, because even if the vendor takes advantage of the wage difference paid to the worker, the grant should not be less than the minimum wages (UMK). Principals and vendors should have taken into account the vendor's profits when drawing up an outsourcing contract / contract agreement with no prejudice to workers' rights.

As noted above, in the author's observation there is an outsourced worker who works in company "B" is not paid wages in accordance with applicable provisions, where wages paid under the provisions of the minimum wage. And ironically in practice in other companies, there is also an outsourced cooperation / contract agreement which contains the contract value payment agreement for the services of workers under the Minimum Wages of City / District (UMK).

The outsourcing contract / agreement must also firmly and clearly determine the amount of worker's wage that the vendor pays along with the vendor's willingness to pay a fine if it does not meet the contractual clauses partly or wholely including the issue of the 
wage of the worker.The firmness and clarity to fulfill the obligation to fulfil the workers' rights is not only about the interests of outsourced workers, but also concerning the principal's responsibility because if the employment rights are not fulfilled then the contract law is null and the responsibility for the workers is transferred to the principal.

c) Terms of Working Hours, Resting Time and Calculation of Overtime Pay.

Article 77 Paragraph (1) of Law Number 13 of 2003 stipulates that every entrepreneur is obliged to implement the provisions of working hours, and the provisions concerning the maximum working hours are stipulated in Article 77 Paragraph (2).

Working hour time exceeding the requirement in Article 77 paragraph (2) is called overtime work with consequences shall be calculated overtime pay. The execution of overtime meets the following requirements:

1. The worker who is required to work longer than the normal working hours agrees to do so

2. Overtime can only be done at most (three) hours a day and 14 (fourteen) hours a week. Regardless of the nature and type of work, the outsourced worker is also entitled to working hours, rest-time and overtime wages, both vendors and principals must implement the provisions stipulated in applicable legislation.

As the author points out above, in the observation of the author of an outsourced worker employed / placed in a company "C" the execution of overtime work and the payment of his overtime wage deviates from the applicable provisions, namely he is imposed "mandatory" overtime work by the amount of overtime work exceeding 3 (three) hours in 1 (one) day and 14 (fourteen) hours in 1 (one) week, calculating the payment of overtime pay not according to the applicable provisions as stipulated in Decree of Minister of Labor 
and Transmigration Number 102/Men/IV / 2004 on Overtime and Overtime Wages.

Outsourced workers have the same right to assure protection from any risks that may arise as a result of the work he does, involving physical, mental, social, moral, and moral risks since the physical and mental abilities of workers as human beings have limitation to work effectively to a certain time limit, which if imposed can lead to physical accidents, mental fatigue and decreasing productivity.

d) Labor Social Security Requirements

The Social Security Program of Labor (Jamsostek) is a form of economic and and social protection. This is because this program provides protection in the form of compensation in money on the reduction of income and protection in the form of services and care / treatment at a time when a worker gets certain risks.

The definition of Jamsostek as set in Article 1 letter 1 of Law Number 3 of 1992 on Security of Labor is a protection for labor in the form of compensation in the form of money as a substitute for part of lost or reduced income and services as a result of events or circumstances that experienced by workers in the form of work accident, illness, pregnancy, maternity, old age, and death.

As stated in Article 2 paragraph (3) of Government Regulation Number 14 of 1993 on the Implementation of the Social Security Program of Workers, that employers employing 10 (ten) persons or more, or paying wages of at least Rp. 1.000.000, - (one million rupiah) a month, must include his workforce in the Social Security program of Labor, consisting of Guarantee in the form of money which includes: Work Accident Insurance (JKK), Death Insurance (JKM), and Old Age Insurance (JHT), as well as service guarantee in the form of Health Care Insurance (JPK) for all workers and their families. 
If we look at the above provisions, the obligation to include workers in the Workers Social Security Program also applies to outsourcing vendors.

One of the facts of the lack of economic protection and social protection for outsourced workers is the exclusion of (outsourced) vendors in the Workers' Social Security Program (Jamsostek) who are employed in "A" and "B" companies while outsourced workers who are employed in company "C" is included (by the vendor) only in the Jamsostek Package A program which includes Work Accident Insurance (JKK), Death Insurance (JKM) and Old Age Insurance (JHT).

\section{E. CLOSING}

\section{Conclusion}

From the above description and discussion, the author draws some conclusions as follows:

a. Outsourcing by hand over of part of work to other companies either through employment contracting agreements or through the provision of general services of workers has not generally implemented all the provisions and Terms of outsourcing as stipulated in Law Number 13 of 2003 on Labor .

b. The implementation of work protection and working conditions for outsourced workers still not given in accordance with the applicable laws and regulations, thus harming workers both in economic and social terms.

\section{Suggestions}

Based on the above conclusions, the author suggests the following things:

a. Every company should make the flow of production activities so that there is clarity and legal certainty about the nature and nature of the core business and the non-business activities of the company as a 
whole, and preferably the company that will hand over part of its work to another company must be thoroughly aware and convinced that the status of the business entity of the company to which it is to be cooperated shall be a legal entity.

b. To implement job protection and work conditions for outsourced workers, the government should enhance its role in the supervision and enforcement of labor law by increasing the quality and quantity of labor inspectors, personnel of labor inspectors, providing facilities and adequate budget to perform the duties and functions of supervision, as well as by improving the competence of labor inspectors through education and training.

c. The government should immediately make the labor law reforms by revising the labor laws and regulations on outsourcing terms and conditions that are no longer in line with the development of the business world, or revising the contradictory provisions, in order to have new provisions on outsourcing that may provide protection to all parties especially to the workers in accordance with the purpose of employment development.

\section{BIBLIOGRAPHY}

\section{Books}

Abdul Khakim, 2007, Pengantar Hukum Ketenagakerjaan Indonesia Berdasarkan Undang-Undang Nomor 13 tahun 2003 (Introduction to the Labour Law Based on Law Number 13 of 2003), Bandung: PT Citra Aditya Bakti.

Adrian Sutedi, 2009, Hukum Perburuhan (Laboyr Law), Jakarta: Sinar Grafika. Asri Wijayanti, 2009, Hukum Ketenagakerjaan Pasca Reformasi (Labour Law By Subsquent of Reformation), Jakarta: Sinar Grafika.

A.Z. Nasution, 2002, Hukum Perlindungan Konsumen (Suatu Pengantar) (Law of The Consumer Protection (As Introduction), Jakarta: Diadit Media. 
Baqir Sharief Qorashi, 2007, Keringat Buruh - Hak Dan Peran Pekerja Dalam Islam (Sweat Workers-Rights and Role of Workers In Islam), Jakarta: AIHuda.

Djoko Triyanto, 2004, Hubungan Kerja Di Perusahaan Jasa Konstruksi (Working Relationship In Construction Service Company), Bandung: Mandar Maju.

Djumadi, 2003, Hukum Perburuhan Perjanjian Kerja (Labor Law of Employment Agreement), PT Raja Grafindo Jakarta Persada.

Eggy Sudjana, 2005, Nasib Dan Perjuangan Buruh Di Indonesia (The Fate and Struggle of Workers In Indonesia), Jakarta: Renaissan.

Esmi Warasih, 2005, Pranata Hukum Sebuah Telaah Sosiologis (Legal Institutions: A Sociological Review), Semarang: PT Suryandaru Utama.

FX Djumiadji, 1987, Perjanjian Pemborongan (Charter Agreement), Jakarta: Bina Aksara.

Hari Supriyanto, 2004, Perubahan Hukum Privat Ke Hukum Publik, Studi Hukum Perburuhan Di Indonesia (Changes to Private Laws to Public Law, Legal Studies of Labor In Indonesia), Jogyakarta: Universitas Atmajaya,

Hidayat Muharam, 2006, Panduan Memahami Hukum Ketenagakerjaan SertaPelaksanaannya Di Indonesia (Guide to Understanding Labor Law and Its Implementation In Indonesia), Bandung: Citra Aditya Bakti.

Iftida Yasar, 2008, Sukses Implementasi Outsourcing (Successful Implementation Outsourcing), Jakarta: PPM. , 2011, Menjadi Karyawan Outsourcing (As Outsourcing Employment), Jakarta: Gramedia Pustaka Utama.

Imam Soepomo, 1999, Pengantar Hukum Perburuhan (Introduction to the Labor Law), Jakarta: Djambatan. , 1986, Hukum Perburuhan Bagian Pertama Hubungan Kerja (Labor Law Part One Employment Relations), JakartaL PP AKRI Bhayangkara.

Ishaq, 2008, Dasar - Dasar Ilmu Hukum (Fundamentals of Legal Science), Jakarta: Sinar Grafika. 
Lalu Husni, 2007, Hukum Ketenagakerjaan Indonesia (Indonesian Labor Law), Jakarta: Raja Grafindo Persada.

Libertus Jehani, 2008, Hak-hak Karyawan Kontrak (Rights of the Contract Employees), Forum Sahabat.

Mochtar Kusumaatmadja, 2006, Konsep-Konsep Hukum Dalam Pembangunan (Legal Concepts In the Development), Bandung: Alumni.

Muchtar Pakpahan Dan Ruth Damaihati Pakpahan, 2010, Konjlik Kepentingan Outsourcing Dan Kontrak Dalam UU No. 13 Tahun 2003 (Cinflicts of Interest between Outsourcing and Contracts), Jakarta: PT Bumi Intitama Sejahtera.

Payaman Simanjuntak, 2003, Manajemen Hubungan Industrial (Industrial Relations Management), Jakarta: Pustaka Sinar Harapan.

Rachmad Syafa'at, 2008, Gerakan Buruh Dan Pemenuhan Hak DasarnyaStrategi Buruh Dalam Melakukan Advokasi (Labor Movement and Fulfillment of Its Basic Rights-Strategy of Workers In Advocating), Semarang: In-TRANS Publishing.

Ridwan Halim, 1987, Sari Hukum Perburuhan Aktual (Act of Labor Law), Jakarta: Pradnya Paramita.

Salim H.S., 2003, Perkembangan Hukum Kontrak Innominaat Di Indonesia (Development of Innominaat Contract Law In Indonesia), Jakarta: Sinar Grafika.

Sehat Damanik, 2006, Outsourcing Dan Perjanjian Kerja Menurut UndangUndang Nomor 13 Tahun 2003 Tentang Ketenagakerjaan (Outsourcing and Work Agreement Based on The Law Number 13 of 2003), DSS Publishing.

Soeroso, 2006, Pengantar Ilmu Hukum (Introduction to Jurisprudence), Jakarta: Sinar Grafika.

Sri Soemantri, 1992, Bunga Rampai Hukum Tata Negara (Potpourri to The Constitutional Law), Bandung: Alumni.

Subekti, 1977, Aneka Perjanjian (Various Agreements), Bandung: Alumni. 
Wiratni Ahmadi, 2006, Perlindungan Hukum Bagi Wajib Pajak Dalam Penyelesaian Sengketa Pajak (Legal Protection For Taxpayers In Tax Dispute Settlement, Bandung: Refika Aditama.

Zaenal Asikin dan Agusfian Wahab, 1993, Dasar - Dasar Hukum Perburuhan (Fundamentals of Labor Law), Jakarta: Raja Grafindo Persada.

Zaeni Asyhadie, 2007, Hukum Kerja-Hukum Ketenagakerjaan Bidang Hubungan Kerja (Employment Law-Employment Law in the Employment Relation), Jakarta: PT Raja Grafindo Persada.

\section{Journal:}

Aloysius Uwiyono, 2003, Implikasi Undang-Undang Nomor 13 Tahun 2003 Terhadap/klim Investasi, Junal Hukum Bisnis Vo1.22 Number5, Jakarta.

\section{Regulations:}

The 1945 Constitution of the Republic of Indonesia.

Law Number 3 of 1992 on Social Security of Labor, State Gazette of The Republic of Indonesia Number 33 of 1992

Law Number 13 of 2003 on Labor Law, State Gazette of The Republic of Indonesia Number 39 of 2003

Law Number 39 Year 1999 on the Human Rights, State Gazette of The Republic of Indonesia Number 165 of 1999)

Decree of the Minister of Labor and Transmigration Number 100 / Men / VI / 2004 on Implementation of Working Agreement of Specified Time Period.

Decree of the Minister of Labor and Transmigration Number 101 / Men / VI / 2004 on Licensing Procedure of Worker / Worker Service Company.

Decree of the Minister of Labor and Transmigration Number 102 / Men / V1 / 2004 on OvertimeWork Hours and Overtime Pay.

Decree of the Minister of Labor and Transmigration Number 220 / Men / X / 2004 on the Condition for the hand-over of Part of Work to Other Companies.

Government Regulation Number 14/1993 on the Implementation of the Workers' Social Security Program 